\title{
Impact of Nitrous oxide(N2O) Concentrations on Atmospheric air Temperature Changes over Iraq and some Neighboring Regions
}

\author{
Swma J. Al-jaf , Osama T. Al-Taai \\ Department of Atmospheric Sciences, College of Science, Mustansiriyah University, Baghdad, Iraq
}

\section{Article Info}

Received: April, 2019

Revised:june, 2019

Accepted:July,2019

\section{Keywords}

Greenhouse gases, N2O, ECMWF, Climate change, Iraq, Neighbor regions.

Corresponding Author

Swmajaff@gmail.com

\begin{abstract}
Iraq one of the most Middle East countries confronts to climate change, where it faced many environmental challenges the most important of high temperatures above the rate of the natural. The Nitrous oxide(N2O) gas work on the absorption of part of the heat inside the atmosphere and prevent the leakage into space and this leads to increase temperature of the air and knows this phenomenon of global warming, $\mathrm{N} 2 \mathrm{O}$ has another effect on the atmosphere as it works to drain the ozone layer that protects the atmosphere from harmful ultraviolet rays. The aim of this research is to study the effect of $\mathrm{N} 2 \mathrm{O}$ to increase their concentration in the atmosphere of temperature variation. Where the data was taken from satellites recorded by the European Centre for medium range weather forecasts (ECMWF). This study choice Iraq and neighbor regions from latitude 27 to $37^{\circ} \mathrm{N}$ and longitude from 39 to $50{ }^{\circ} \mathrm{E}$ for years (2003-2016), where we studied the behavior of $\mathrm{N} 2 \mathrm{O}$ gas concentration and its relationship with air temperature variation. The result by using correlation coefficient between $\mathrm{N} 2 \mathrm{O}$ and temperature it found that the relationship was high positive in the all stations of study, where in Sulamaniyah (Iraq) +0.8 , and also be a strong positive relationship in southern stations, as for neighboring regions also be high positive in Batman (Turkey) +0.7 , and Amman (Jordan) +0.8 also in Aleppo(Syria) +0.8 , and in Jubail (K.S.A) correlation coefficient +0.8 , and in Ahwaz (Iran) be +0.8 .
\end{abstract}

\section{Introduction}

Nitrous oxide is a chemical compound, and its chemical formula $\mathrm{N} 2 \mathrm{O}$ is a colorless, nonflammable gas with mild metallic odor at normal temperature. At high temperatures, nitrous oxide is a strong oxidant like molecular oxygen. Soluble in water[1].

Most of the nitrous oxide found in the atmosphere is produced from natural and human sources. Microorganisms such as bacteria and fungi present in soil, under natural vegetation, are an important source of nitrous oxide, accounting for $60 \%$ of the total naturally produced emissions[2]. Other natural oceans
(35\%) have atmospheric chemical reactions (5\%)[3]. As for human emissions, it is the fertilized agricultural soils and compost, surface runoff and biomass burning, burning of fossil fuels and industrial processes, biological degradation of other nitrogen-containing emissions [4][5]. N2O emissions from soil may be difficult to measure because they change markedly over time and space, and most of the year's emissions may occur when conditions are favorable during hot moments [6].

Nitrous oxide has the effect of global warming as a greenhouse gas. Based on each molecule, it was considered over a 100-year period, and 
nitrous oxide has 298 times the thermal capture capacity of carbon dioxide [7]. However, the effect of N2O in greenhouse gases is less than carbon dioxide, water vapor and methane due to its low concentration in the atmosphere[8]. As well as nitrous oxide have a significant role in the depletion of the ozone layer Recent studies indicate that emissions of nitrous oxide at present the most important ozone-depleting substances, and is expected to remain the largest during the twenty-first century [9]. Abbood, Z. M., Al-Taai, O. T.,(2018) studied of Absorbance and Emissivity Solar Radiation by Clouds, Aerosols and some Atmospheric gases[10],for this study used data were taken from the satellites of the European Center for Meteorological Forecasts ECMWF[11]. Rashed, S. M., Al-Taai, O. T.(2017), studied Analysis study of Meteorological Parameters and their Relationship with some Concentration of Tropospheric Gases over Erbil City[12].

\section{The study stations}

Iraq is country in Western Asia spanning most of the northwestern end of the Zagros mountain range, the eastern part of the Syrian Desert and the northern part of the Arabian Desert. The desert is in the southwest and central provinces, along the borders with Saudi Arabia and Jordan and geographically belongs with the Arabian Peninsula. The climate of Iraq is characterized by sub-tropical, continental, arid to semi-arid with dry hot summers and cooler winters. The average annual temperature is varies from $8.5{ }^{\circ} \mathrm{C}$ to $49{ }^{\circ} \mathrm{C}$. The summer temperature range is between $16 \mathrm{oC}$ to $49 \mathrm{oC}$, while winter temperature range is between 8.5 $\mathrm{oC}$ to $14 \mathrm{oC}$. The work was carried with the monthly mean of the years (2003-2016) the H2O and Temperature data taken from the European center medium weather forecasts (ECMWF) specifically model (ERA-interim), this data was taken over Iraq and neighbor regions where chosen for this work located at the latitude SW $(27,37) \mathrm{oN}$ and longitude NE $(39,50) \mathrm{oE}$ with spatial resolution $2 * 2.5$ degree as shown in Figure (1), and table(1).

\section{Statistical used}

Choosing spearman (Rho) from many statistical tests has been selected regression analysis .Using statistical program sigmaplot[13] to figure out the slope of regression, and p-value simple linear regression way to detect the relationship between the gas concentration and temperature by simple linear regression. And using sufer13 program [14] to show gas and temperature behavior in study stations ,and used GIS to draw study stations map.

\section{Result and Discussion}

\section{Study the behavior of monthly mean of Temperature in study stations}

Figure(2) show the behavior of monthly mean of temperature, during the study(2003-2016) it founded that the highest temperature in the southern stations of Iraq in the August, and the lowest temperature in the January, while in the neighbor stations temperature less than Iraqi stations ,just Jubail stations in Saudi Arabia has temperature like the southern stations of Iraq ,because it has high concentration of greenhouse gases jubail was industry region therefore has high pollutions. See Figure (2).

\section{Study the behavior of the monthly mean} of $\mathrm{N}_{2} \mathrm{O}$ in study stations

Figure(3) show the behavior of the monthly mean of $\mathrm{N}_{2} \mathrm{O}$ gas during the study period(2003-2016) for Iraq and neighboring regions. The study shows that concentrations of gas $\mathrm{N}_{2} \mathrm{O}$ increase in winter (December, January and November) and increase during the spring (March, April and May) but this increasing in gas concentration in spring less than winter, the highest value during the winter in January $0.000666 \mathrm{ppm}$ in the city of Aleppo in Syria and also increase the concentrations of $\mathrm{N}_{2} \mathrm{O}$ in the northern parts of Iraq Mosul, Baghdad and Basrah, either during the spring of the highest 
concentration of gas in May was the highest concentrations of nitrous oxide 0.000617 ppm in the Aleppo in Syria and also the concentration of gas in the city of Baghdad in May $0.000617 \mathrm{ppm}$. The gas concentrations are high in the southern parts of Iraq and especially in the Basrah station. During the summer (June, July and August) and during the autumn season (September, October and November), noticed a significant reduction in gas concentration for neighboring Iraq, During the summer, the highest concentrations of nitrous oxide $\left(\mathrm{N}_{2} \mathrm{O}\right)$ are in July, with a concentration of $0.000616 \mathrm{ppm}$ in Baghdad station. During autumn, the highest concentration of gas is in November with a concentration of $0.00061 \mathrm{ppm}$ in Aleppo, Syria. High concentrations of nitrous oxide $\mathrm{N}_{2} \mathrm{O}$ are produced from fuel combustion, power plants and transport (cars and aircraft) When fuel is burned, the primary oxides are nitrogen, nitrogen oxides and nitrogen dioxide $\mathrm{NO}_{2}$. The general name of these oxides is. $\mathrm{NO}_{2}$. These compounds are not directly formed as a result of fuel combustion but as a result of chemical reactions between nitrogen and oxygen in the air at high temperatures resulting from the burning of fuel in power plants and engines. Nitrogen oxides are composed at high temperatures between $1600-3000{ }^{\circ} \mathrm{C}$. The first nitrogen oxide, a colorless and odorless gas, then oxidizes again to become nitrogen dioxide. This gas is a red color. These gases can stay in the atmosphere for three to four days and then part of it reacts with the water vapor in the air to be nitro genic acids which cause acid rain formation. Transport and power plants are the main sources of pollution that lead to the release of large quantities of nitrogen in the engines of cars related to the size of the engine and the speed of the car The higher the speed of the car the greater nitrogen oxides result, because the result of high speed increase the amount of nitrogen entering the engine. Nitrogen oxides cause significant damage and are a major factor in the production of chemical light smog, which is the main problem of pollution of major cities in the world, especially industrial cities, Nitrous oxide $\left(\mathrm{N}_{2} \mathrm{O}\right)$ causes severe damage to plants, damaged colors and fabrics, and leads to corrosion of metals in high concentrations of nitro genic acids. High concentrations of nitrous oxide cause depletion of the ozone layer. See Figure (3).

The total yearly mean of Temperature in study stations

Figure(4) show behavior of the total average temperature the highest temperatures are in Baghdad $\left(26.2^{\circ} \mathrm{C}\right)$, and the temperature is high in the southern regions where it is in Basrah $\left(26.8^{\circ} \mathrm{C}\right)$. Also, the temperature is high in Hadithah station, western Iraq $\left(25.5^{\circ} \mathrm{C}\right)$ And temperatures are lower in the rest of Iraq. As for the neighboring regions, the highest temperature during the study period is in Jubail station in( K.S.A) the temperature was $\left(27^{\circ} \mathrm{C}\right)$ and was lower in the other neighboring regions, and the lowest rate of temperature was in Batman station in (Turkey )due to the lack of greenhouse gases emissions in this region compared to the other stations . See Figure (4)

The total yearly mean of Nitrous oxide in study stations

Figure(5) show behavior of total yearly mean of $\mathrm{N} 2 \mathrm{O}$, the highest concentrations of gas was in Baghdad where the concentration (0.000599 ppm) because of the fact that Baghdad is a populated area and a large number of cars and 
the presence of the airport also have a role in increasing nitrous oxide as it is produced from the internal combustion of aircraft engines, The concentration of $\mathrm{N} 2 \mathrm{O}$ is relatively high in the southern regions, specifically in Basrah, where the concentration is $0.000570 \mathrm{ppm}$. In Mosul station the concentration of gas is high $(0.000507 \mathrm{ppm})$ but the value of gas is lower in the western region of Iraq, where the concentration of gas in the Hadithah station (0.000467 ppm), for neighboring regions the highest concentration of gas was in Aleppo (Syria) The concentration shall be $0.000598 \mathrm{ppm}$ and less concentration in other neighboring regions, See Figure (5)

\section{Scatter plot between $\mathrm{N}_{2} \mathrm{O}$ and Temperature}

Figure(6) show correlation coefficient between the monthly mean of nitrous oxide $\left(\mathrm{N}_{2} \mathrm{O}\right)$ and the temperature during the study period (20032016) for Iraq and neighboring regions in order to determine the strength of the relationship between increasing the gas concentrations and the temperature of the study stations, found that the relationship between gas concentrations and temperature is a positive relationship for Iraq to be the largest coefficient of correlation between gas and temperature in the southern regions of Iraq, where in Basra the value of correlation coefficient (+0.8) and in the city of Nasiriya, which is located in southern Iraq, (0.8). The maximum value of the correlation coefficient between the gas and heat concentrations in the northern regions of Iraq is determined by the value of the correlation between gas and temperature in Sulaymaniyah city $(+0.8)$.

As for neighboring regions of Iraq, the highest correlation coefficient (Spearman) in Ahwaz in Iran and Jubail in Saudi Arabia and also in Aleppo in Syria, where the value of correlation coefficient in these areas $(+0.8)$, and in Batman in Turkey is the value of the correlation coefficient between gas (+0.7), and at Amman station in Jordan $(+0.6)$. It has been shown that there is a very positive relationship between the increase in nitrous oxide concentration in the atmosphere and the high temperature during the study period. This positive relationship between nitrous oxide and temperature makes $\mathrm{N} 2 \mathrm{O}$ one of the greenhouse gases that causes high atmospheric temperatures and the occurrence of warming Thermal and associated climate changes. See Table (2)

$\&$ See Figure (6).

\section{Conclusions}

1 - By studying the behavior of monthly nitrous oxide, found that their concentrations fluctuate from month to month and from season to season due to several factors such as rain and temperature.

2. The highest concentration of nitrous oxide in Baghdad and southern stations of Iraq, as well as in the surrounding regions was the highest concentration in Aleppo in Syria due to the large number of sources that emit nitrous oxide into the atmosphere such as burning fossil fuels and waste disposal.

3 - $\mathrm{N}_{2} \mathrm{O}$ gas relationship with the temperature of a strong positive relationship in most stations, where this gas works with other greenhouse gases to lock the heat and prevent the leak into space, causing high temperature of the atmosphere, as well as nitrous oxide works to drain the ozone layer and thus access UV rays are harmful to the surface of the earth and cause a lot of damage to living organisms.

4. Nitrous oxide $\left(\mathrm{N}_{2} \mathrm{O}\right)$ is one of the greenhouse gases that works to raise the average temperature of the Earth from normal with other gases and thus the occurrence of global warming. 
Acknowledgement

An acknowledgment to the European Center

Medium Weather Forecasts (ECMWF) on

the data used in this study, and we would also like to thanks mustansiriyah university for providing scientific support to accomplishing this research.

\section{References}

[1] Tarendash, A.S., Let's review: chemistry, the physical setting (3rd ed.). Barron's Educational Series, 2001( ISBN 978-07641-1664-3): p. p. 44.

[2] Sloss, L.L., Nitrogen Oxides Control Technology Fact Book. William Andrew, 1992. (ISBN 978-0-8155-1294-3): p.p. 6.

[3] Methane and Nitrous Oxide Emissions from Natural Sources. US Environmental Protection Agency 2010(Report EPA 430-R10-001).

[4] K. L. Denman, G. Brasseur, et al.(2007), "Couplings Between Changes in the Climate System and Biogeochemistry". In Fourth Assessment Report of the Intergovernmental Panel on Climate Change, Cambridge University Press.

[5] IPCC. 2013. Climate change: the physical basis (WG I, full report). p. 512.

[6] Molodovskaya, M.; Singurindy, O.; Richards, B. K.; Warland, J. S.; Johnson, M.; Öberg, G.; Steenhuis, T. S. (2012). "Temporal variability of nitrous oxide from fertilized croplands: hot moment analysis". Soil Science Society of America Journal. 76 (5): 1728-1740.
[7] Overview of Greenhouse Gases Nitrous Oxide". US EPA. 2014-06-10. Page 164 (document header listing). Retrieved 19 March 2014.

[8] US Environmental Protection Agency, "Climate Change Indicators: Atmospheric Concentrations of Greenhouse Gases" Web document, accessed on 2017-02-14.

[9] 4.1.1 Sources of Greenhouse Gases". IPCC TAR WG1 2001. Archived from the original on 29 October 2012. Retrieved 21 September 2012.

[10] Abood, Z. M and Al-Taai, O. T(2018), Study of Absorbance and Emissivity Solar Radiation by Clouds, Aerosols and some Atmospheric gases. Journal of Applied and Advanced,3(5):p.128-134.

[11] Reanalysis at ECMWF, "The European Center for Medium -Range Weather Forecasts"

.Available(http://ecmwf.int/research/era/do/ get/Reanalysis_ECMWF).[Accessed:06-

Oct-2018].

[12] Rashed, S .M and Al-Taai, O. T(2017), Analysis study of Meteorological Parameters and their Relationship with some Concentration of Tropospheric Gases over Erbil City.ZANCO journal of pure and Applied Sciences,29(S4):P.234-248.

[13] Sigmaplot .Scientific Data Analysis and Graphing Software [Web] ; Available: www.sigmaplot.co.uk/products/sigmaplot/si gmaplot-details.php.

[Accessed 05/02/2019].

14]Sufer13programhttp://www.mediafire.co m/download/acjlce0uhxx1npn/SURFER.pdf 


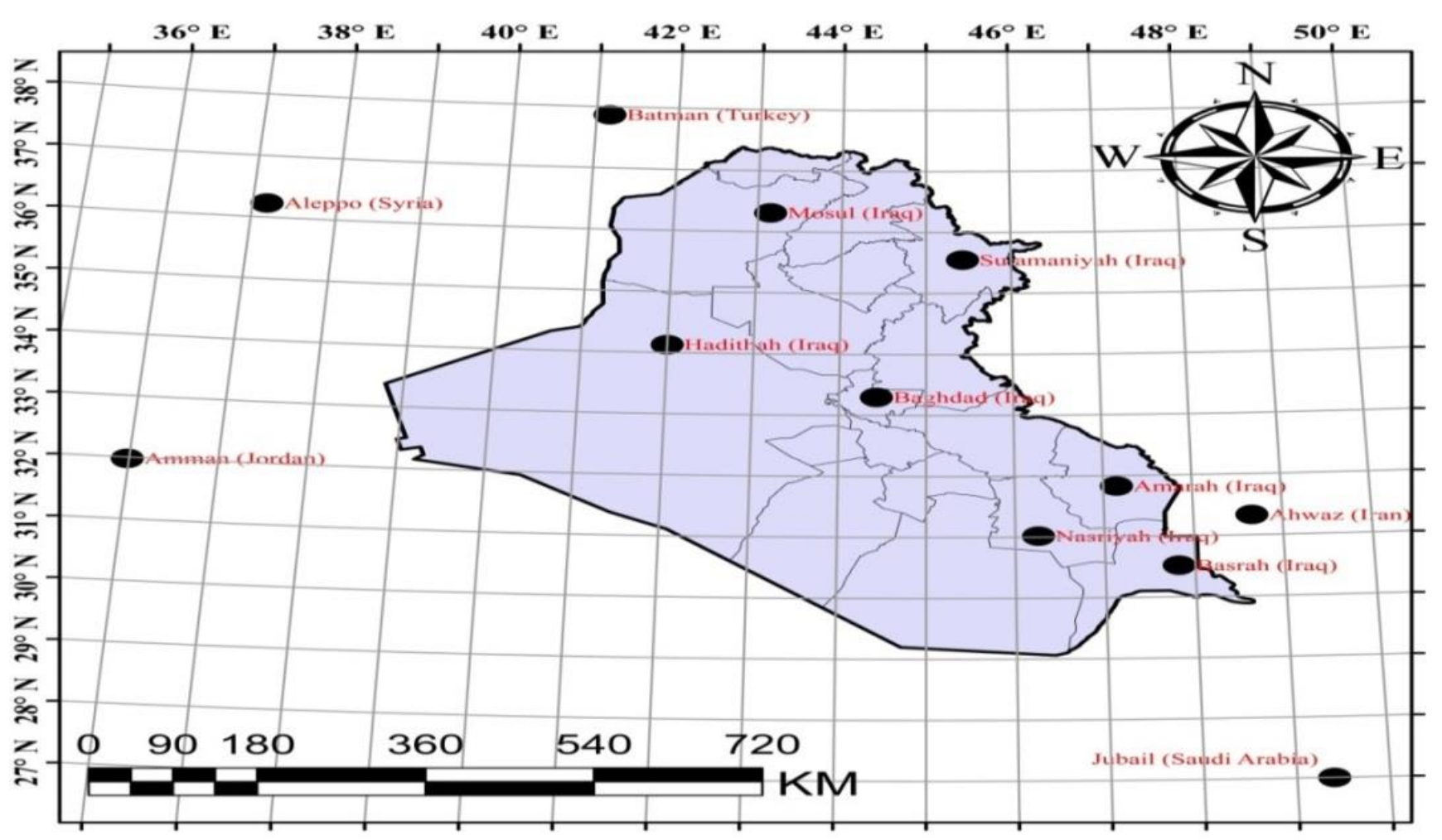

Figure (1) study stations

Table (1). Location and Altitude for study stations from north to south .

Stations

Batman (Turkey)

Mosul (Iraq)

Aleppo (Syria)

Sulamaniyah (Iraq)

Hadithah (Iraq)

Baghdad (Iraq)

Amman (Jordan)

Amarah (Iraq)

Ahwaz (Iran)

Nasriyah (Iraq)

Basrah (Iraq)

Jubail (Saudi Arabia)
Longitude $\left({ }^{\mathrm{o}} \mathrm{E}\right) \quad$ Latitude $\left({ }^{\mathrm{O}} \mathrm{N}\right)$

37.87

36.31

36.23

35.55

34.13

33.30

31.98

31.83

31.33

31.02

30.52

28.00
Altitude above sea level (meter)

601
223
379
882
80
34
750
10
21
9
5
7




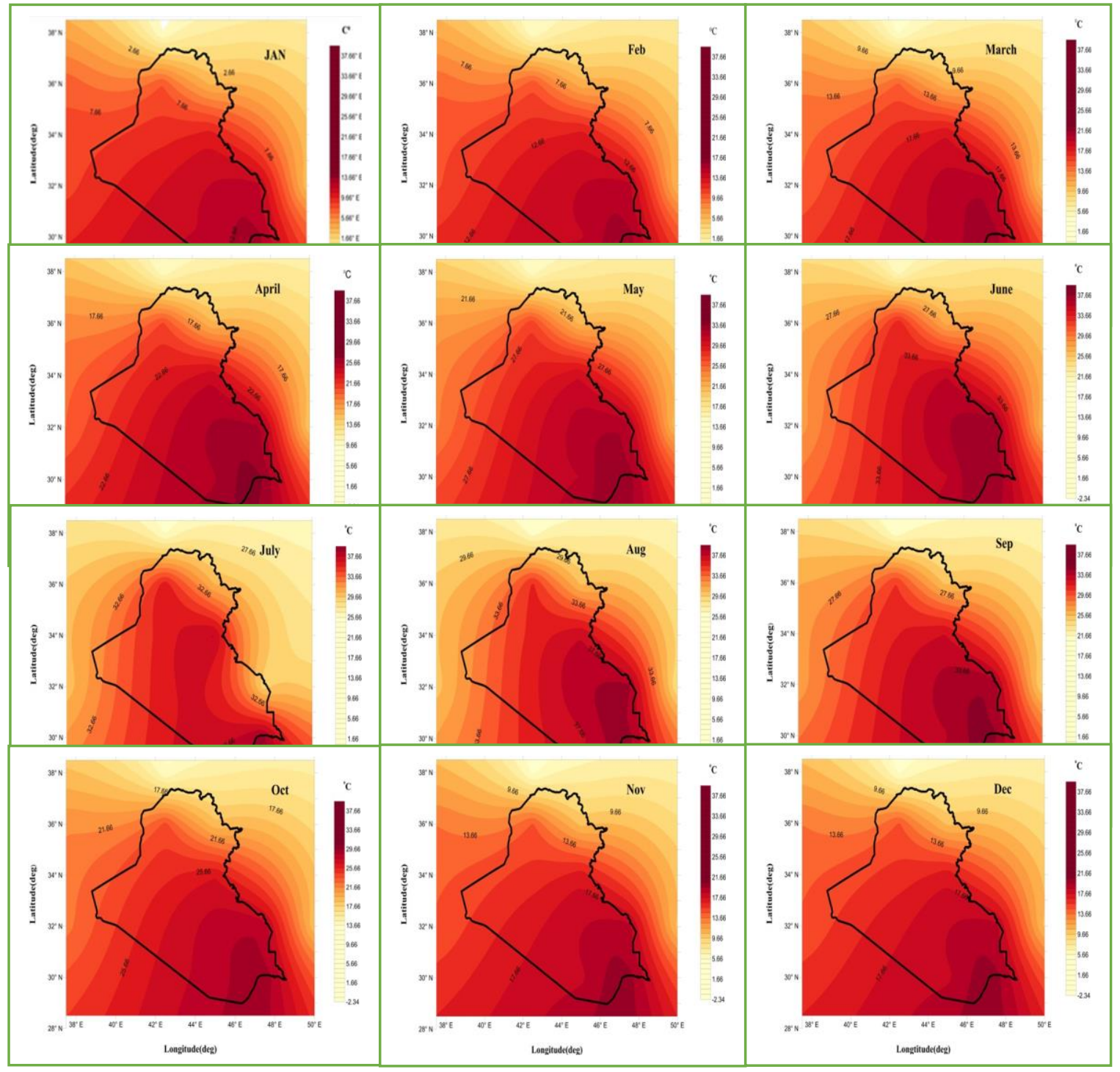

Figure (2) Behavior of the monthly mean of temperature during period(2003-2016) in Study stations $\left({ }^{\circ} \mathrm{C}\right)$ 


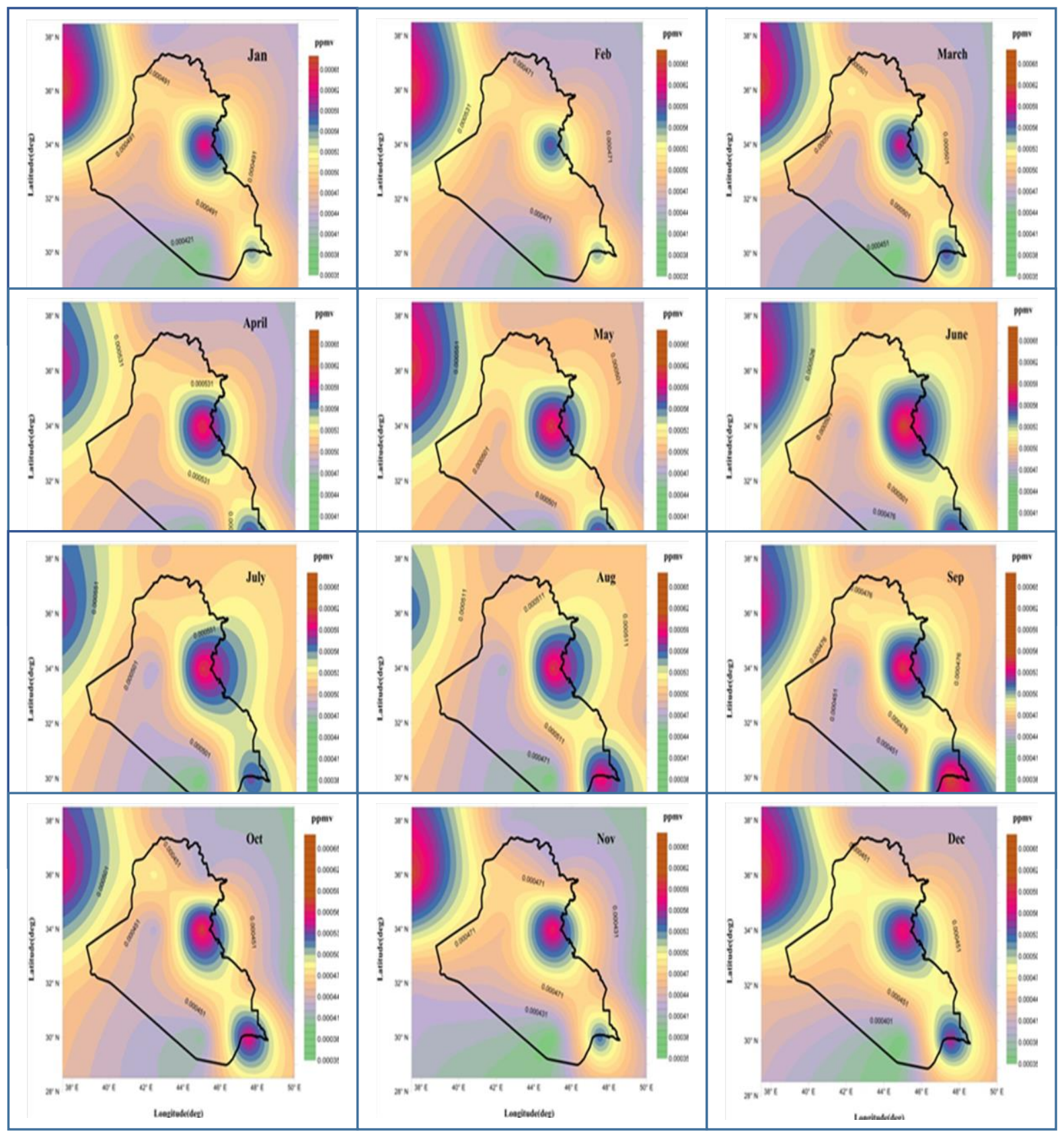

Figure (3) Behavior of the monthly mean of $\mathrm{N}_{2} \mathrm{O}$ during period(2003-2016)in study stations 

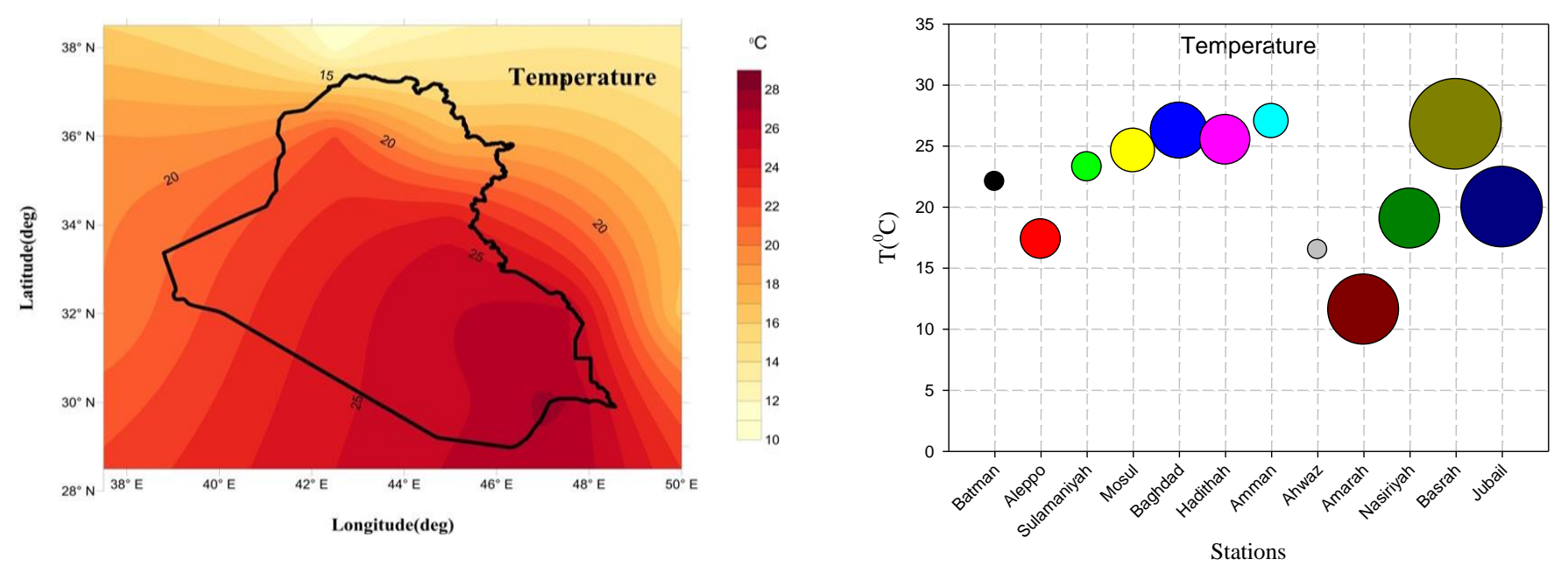

Figure(4) show behavior of the total yearly mean of the temperature in study stations during period (2003-2016)
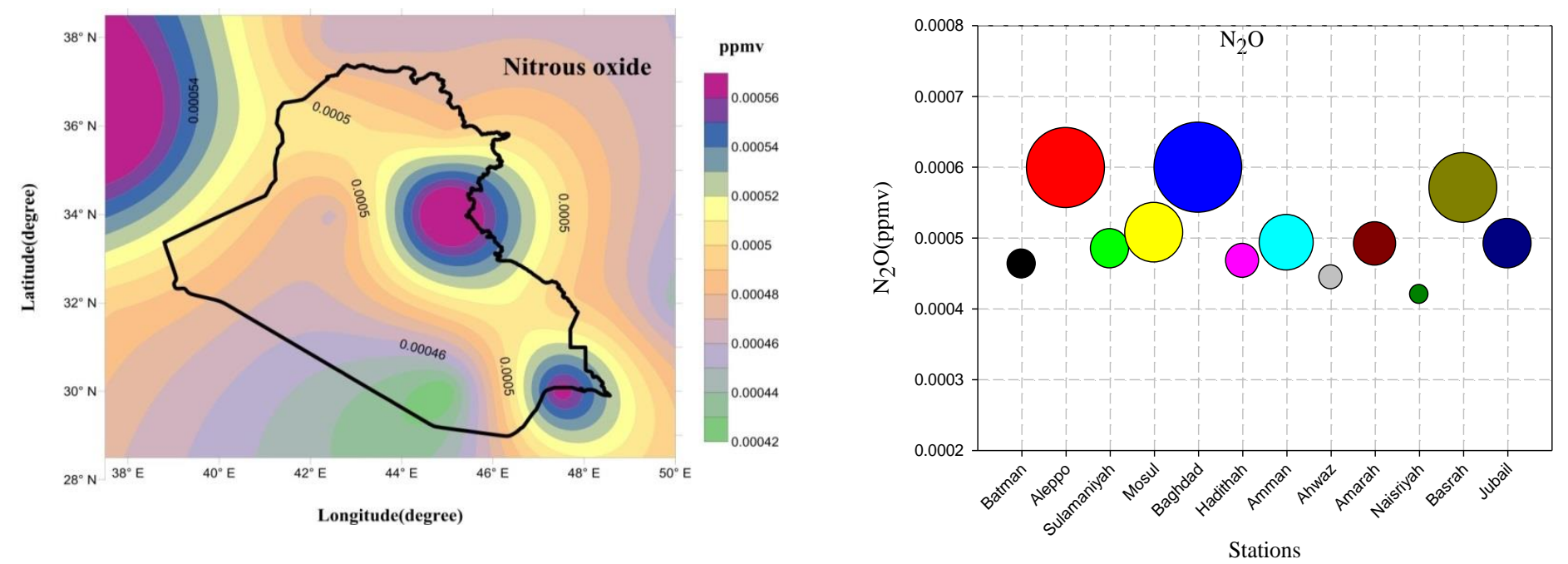

Figure(5) show behavior of the total yearly mean of $\mathrm{N}_{2} \mathrm{O}$ in study stations during period (2003-2016) 
Table (2) The relationship between $\mathrm{N}_{2} \mathrm{O}$ and Temperature in study stations for period (20032016) by using spearman correlation coefficient

\begin{tabular}{|c|c|c|c|c|}
\hline \multirow{2}{*}{$\begin{array}{l}\text { Study Area } \\
\text { Stations }\end{array}$} & \multicolumn{2}{|r|}{ Spearman rho } & \multicolumn{2}{|c|}{ Simple linear regression } \\
\hline & $\mathrm{R}$ & Correlation degree & P-value & $\begin{array}{l}\text { Interpretation of } \\
\text { relationship }\end{array}$ \\
\hline Batman(Turkey) & 0.7 & high positive correlation & 0.007 & Linear regression \\
\hline Mosul(Iraq) & 0.2 & low positive correlation & 0.6 & Non-linear regression \\
\hline Aleppo(Syria) & 0.8 & high positive correlation & 0.003 & linear regression \\
\hline Sulamaniyah(Iraq) & 0.8 & high positive correlation & 0.002 & Linear regression \\
\hline Hadithah(Iraq) & 0.3 & low positive correlation & 0.7 & Non-linear regression \\
\hline Baghdad(Iraq) & 0.1 & Low positive correlation & 0.8 & Non-linear regression \\
\hline Amman(Jordan) & 0.6 & $\begin{array}{l}\text { moderate positive } \\
\text { correlation }\end{array}$ & 0.04 & Linear regression \\
\hline Amarah(Iraq) & 0.6 & $\begin{array}{l}\text { moderate positive } \\
\text { correlation }\end{array}$ & 0.04 & linear regression \\
\hline Ahwaz(Iran) & 0.8 & high positive correlation & 0.01 & Linear regression \\
\hline Nasriyah(Iraq) & 0.8 & high positive correlation & 0.002 & linear regression \\
\hline Basrah(Iraq) & 0.8 & high positive correlation & 0.002 & linear regression \\
\hline Jubail(Saudi Arabia) & 0.8 & high positive correlation & 0.001 & linear regression \\
\hline
\end{tabular}

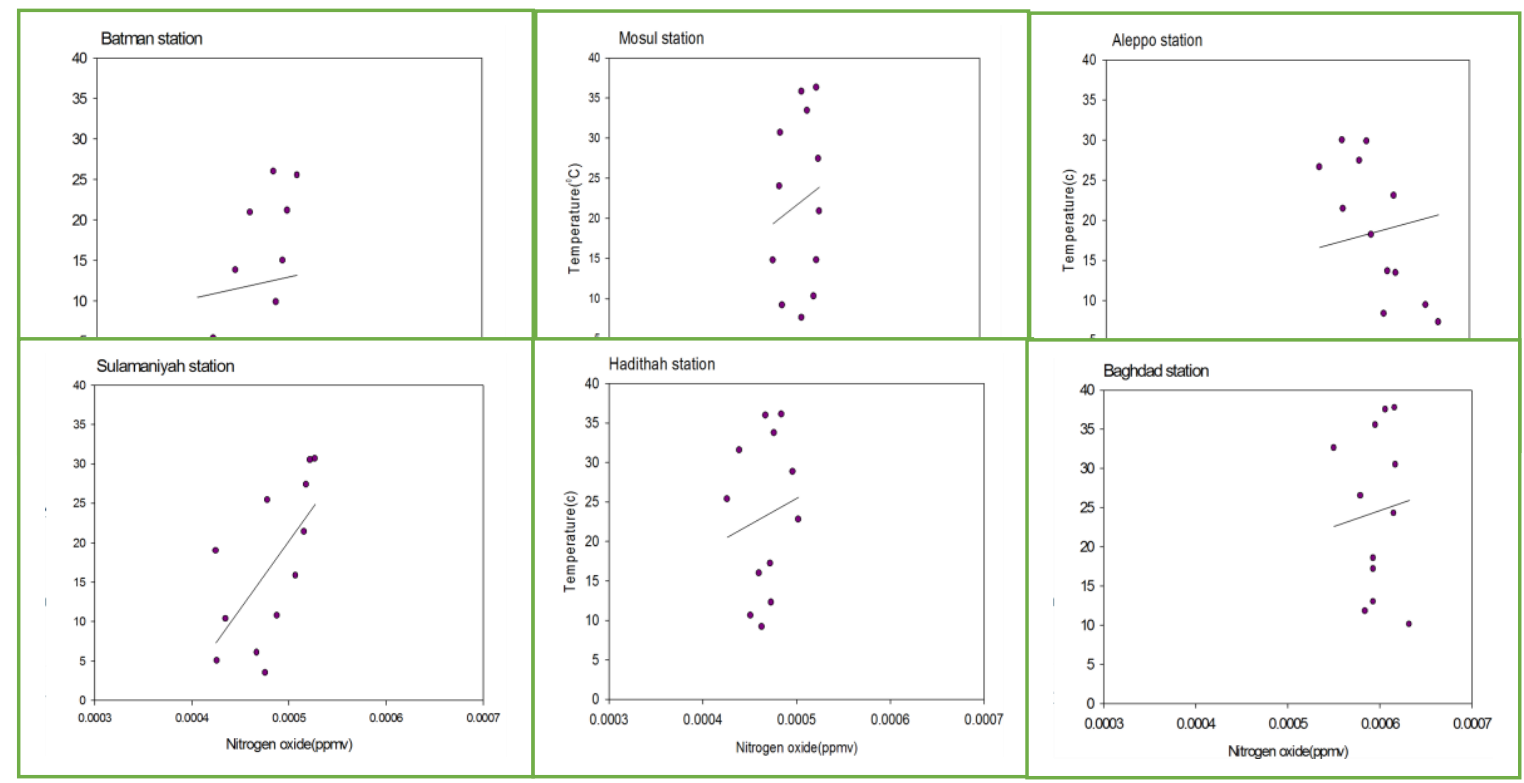

Figure (6) Relationship between $\mathrm{N}_{2} \mathrm{O}$ and Temp. for period(2003-2016) for study stations 


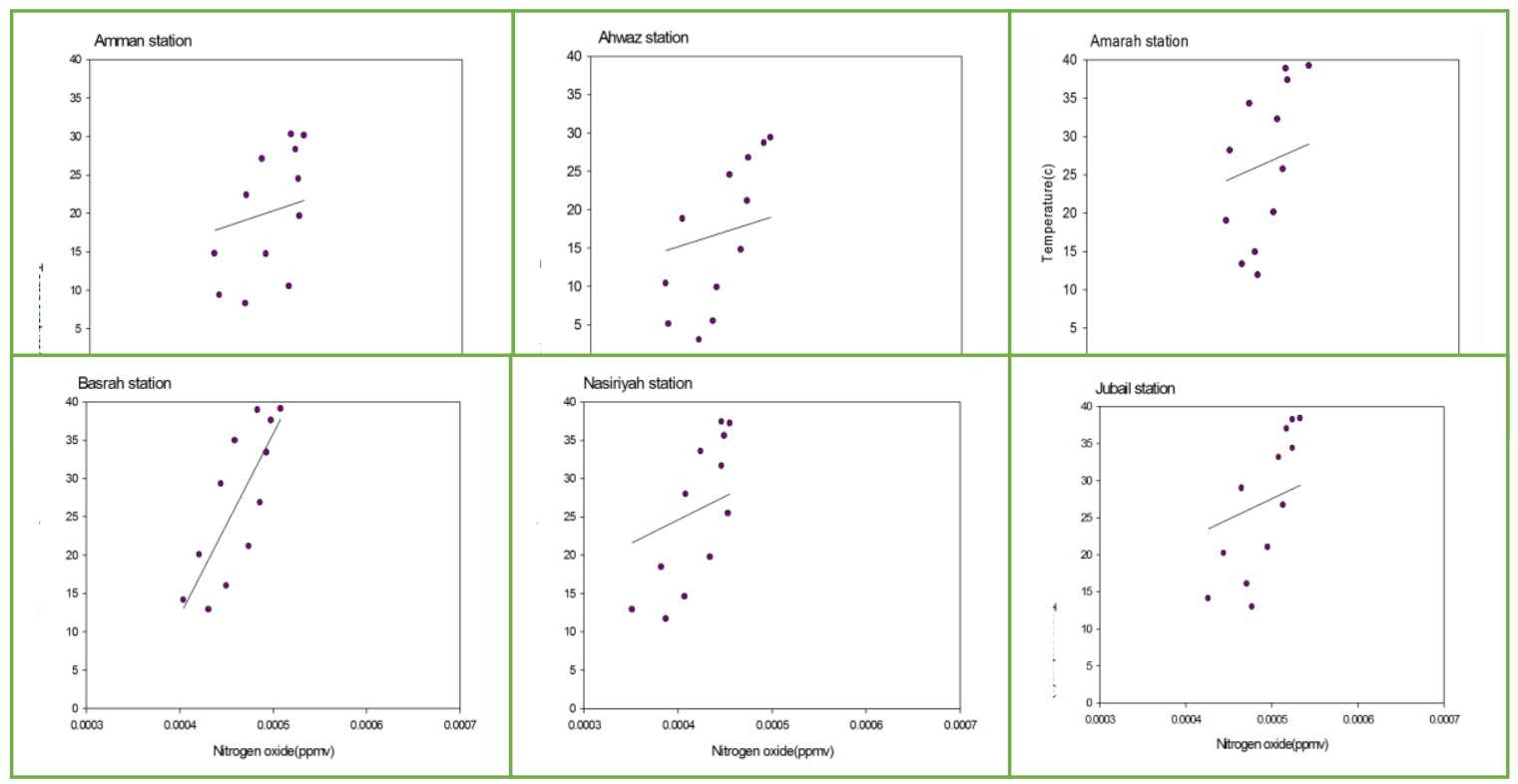

Follow the figure (6) 